\title{
Teddy Theodore Hebert, 1914 to 1998
}

\author{
Robert Aycock and Guy V. Gooding, Jr.
}

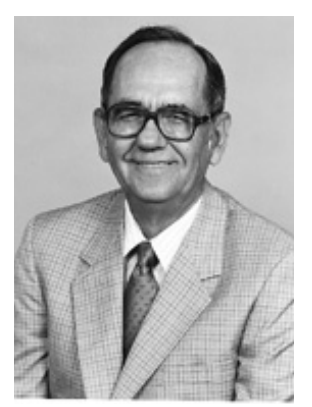

Teddy Theodore Hebert, professor emeritus, Department of Plant Pathology, North Carolina State University (NCSU), died suddenly on 25 April 1998.

Dr. Hebert was born on 24 November 1914 near Lafayette, LA. He graduated with honors from Southwestern Louisiana University in 1938 and received a M.S. degree at Louisiana State University in 1940 . His graduate work toward a Ph.D. degree at NCSU was interrupted by World War II, in which he served as a meteorologist in the Aleutian Islands. Returning to North Carolina in 1946, he quickly completed requirements for a Ph.D. degree, which was awarded at that time by the University of North Carolina at Chapel Hill based on work performed on the Raleigh campus.

Dr. Hebert accepted an appointment to the faculty of Plant $\mathrm{Pa}$ thology at NCSU immediately after graduation and served in this capacity for some 30 years. His research programs included studies on peanut diseases and cereal grains. Dr. Hebert cooperated for many years with Dr. Gordon K. Middleton in a breeding program on cereals, a program noted not only for its outstanding accomplishments, but also for the amiable spirit of mutual helpfulness exhibited by both participants.

Early in Dr. Hebert's career, he became interested in virus diseases and was for many years the department's principal resource in this area. He was noted for his keen intelligence, insight, and broad knowledge in the entire field of plant pathology. Reading widely and possessing an almost photographic memory, his counsel was continually sought by both students and faculty. His knowledge of mycology, statistics, virology, and other basic disciplines was little short of amazing. A modest individual, his principal enjoyment was in the pursuit of knowledge for its own sake; he was never motivated by the possibility of recognition or awards.

In addition to his contributions to North Carolina agriculture, Dr. Hebert participated in numerous international studies and programs. In 1980, he was a member of a team of scientists who assessed pest control problems and determined the feasibility of integrated crop protection systems in a number of African countries. In Columbia, Dr. Hebert conducted basic research principally on the rice blast fungus, one of the most important pathogens of rice in South America and the Orient. His research led to a better understanding of the biology of the pathogen and contributed to the development of resistant varieties. Dr. Hebert was also a valued collaborator in the department's long-standing cooperative program in Peru, and he advised numerous graduate students from this country and abroad.

For many years, Dr. Hebert taught courses in mycology and virology, and his students claimed that "he had the most fantastic knowledge of biology" of anyone in their experience. His knowledge, interest, and helpfulness have been equaled by few.

During 1962 to 1963 , Dr. Hebert taught virology as a Fullbright Professor at the University of Alexandria, Egypt. His scholarly achievements were recognized by invitations to memberships in the Society of the Sigma Xi, Alpha Zeta, Phi Kappa Phi, and Gamma Sigma Delta. The latter organization presented him with a Certificate of Merit for outstanding contributions to his profession, especially in the area of cereal pathology. Dr. Hebert was active in the affairs of The American Phytopathological Society and once served as president of its Southern Division. He was named the Outstanding Plant Pathologist in the South in 1975.

Dr. Hebert was a direct descendant of the Acadians who settled in Louisiana in the mid-1700s. He grew up in a home and in a Louisiana parish where French was the preferred language, and he maintained a fluency in French all of his life, often being called upon by colleagues to be an intermediary in communications with French-speaking colleagues.

Shortly after World War II, Dr. Hebert married Nell Heidleberg, whom he had known during his student days at Southwestern Louisiana University at Lafayette. Nell, a history major, was an outstanding and well-known teacher in the Raleigh public schools for many years. They had four children, Dr. Stephen Hebert of Winston-Salem, NC; Thomas Hebert of Washington, DC; Linda Hebert, and Michael Hebert, both of Raleigh. Mrs. Nell Hebert died in 1988.

For the last 9 years of his life, Dr. Hebert was married to Mrs. Rita Reynolds, who survives him. She was the widow of a veteran member of the Horticulture faculty and was for many years the popular and efficient departmental secretary for the Department of Entomology at NCSU. In their retirement years, Ted and Rita shared many common interests and enjoyed traveling, golfing, gardening, and other recreational pursuits.

Dr. Hebert is also survived by a brother, Didier Hebert of Lafayette, LA; a sister, Bea Hebert Richoux of Marrero, LA; devoted stepdaughters, Debbie Choate of Rocky Mount, NC, Kay Holland of Cary, NC, and Pam Wilser of Cary, NC; and 12 grandchildren. 